\title{
A Preliminary Study on the Framework System of Social Work for Student Party Building in Higher Education
}

\begin{abstract}
Xu Chengtao ${ }^{1, \mathrm{a}}$
${ }^{1}$ Qingdao University of Science and Technology Law School, Qingdao, Shandong, China

a873963773@qq.com

Qingdao University of Science and Technology Teaching Reform Research Project "Research on Social Work Projectbased Practice Teaching Model Based on Cultivation of Applied Personnel" Mid-term Results

ABSTRACT

The introduction of social work into the party building work of students in universities is an inevitable requirement for the localization of social work and the need to further develop the special services of social work for party building of students in universities. In the service process of social work for university students' party building through the questionnaire method of researching the needs of university students, based on the professional theory of social work such as ecosystem theory and the professional method of group work social work as a link, social work services are provided for student party organizations, student party members and students, party members' voluntary services, to explore the theoretical framework of social work for university students' party building for the first time and promote university students' party building. It also promotes the development and research in the field of social work theory and practice.
\end{abstract}

Keywords: Students in higher education, Student Party Members, Party Social Work, Framework system

\section{高校学生党建社会工作框架体系初探}

\author{
徐成涛 1 , a
}

\begin{abstract}
1 青岛科技大学法学院, 青岛, 山东, 中国 a873963773@qq.com
\end{abstract}

青岛科技大学教学改革研究项目 “基于应用型人才培养的社会工作项目制实践教学模式研究 “中期成果 摘要

将社会工作引入高校学生党建工作中, 是社会工作本土化的必然要求, 也是进一步发展高校学生党建社会工作 特色服务的需要。在高校学生党建社会工作的服务过程中通过调查问卷法调研高校学生需求, 以生态系统理论 等社会工作专业理论为依托，以小组工作社会工作专业方法为纽带，针对学生党组织、学生党员及学生、党员 志愿服务等方面提供社会工作服务, 初探高校学生党建社会工作的理论框架，推动高校学生党建社会工作理论 与实务领域的发展与研究。

关键词：高校学生，学生党员，党建社会工作，框架体系

\section{1. 问题的提出}

社会工作在一百多年的本地化过程中对于党建 社会工作的研究较少, 由于党建是中国特有的领域之 一, 在社会工作本土化过程中也没有得到足够的重视。 习近平总书记多次强调, 高校肩负着培育中国特色社 会主义事业接班人的重大任务, 必须毫不动摇的加强
党对高校的领导, 改进高校党建工作。随着新时代的 到来, 高校学生基层党组织作为高校党建工作的前端 触角, 是党的路线方针政策落实的基础。

近年来, 国内对于高校学生党建社会工作的研究 颇多, 对文献进行梳理将有关高校学生党建社会工作 的研究分为三类: 
第一类是社会工作专业融入高校学生党组织建 设。程丙、刘佳通过运用社会工作方法实现“学习型” 党支部、“服务型” 党支部、“创新型” 党支部的转变 与发展 $[1]$ 。第二类是社会工作专业介入高校学生党建 工作组织领导、教育培养、发展党员、党员管理、作 用发挥和条件保障等过程的相关研究。魏爽探讨了新 时期入党积极分子培育新模式, 尝试将 “小组工作” 方法介入高校学生党建领域[2]。第三类是运用社会工 作专业方法解决高校学生党建工作困境的相关研究。 万艳面对新时代高校学生党建工作存在的困境, 以互 构性治理的视角从价值理念、理论传统、专业方法三 方面提升高校学生党建工作的有效性[3]。

虽然之前的文献已经从多角度多方面研究了社 会工作专业参与高校学生党建工作的具体方式, 但没 有对高校学生党建社会工作内容进行系统化概述, 实 务方面更是风毛麟角。基于此, 本文尝试从党建社会 工作领域探讨高校学生党建社会工作的框架体系构 建, 运用 “生态系统理论”、“小组社会工作” 等社会 工作专业理论方法, 提出高校学生党建社会工作的服 务内容主要分为学生基层党组织服务、学生党员服务、 党员志愿者服务、党务工作服务等四部分, 从而进一 步提升高校学生党建社会工作与高校学生党建工作 的高度契合性。

\section{2. 高校学生党建社会工作的理论梳理}

\section{1. 高校学生党建社会工作发展的必要性}

目前, 高校学生基层党组织在实施入党教育、价 值观教育等过程中面临着诸多挑战。首先, 改革开放 以来, 集体主义价值观就受到市场经济社会的巨大冲 击, 社会功利主义的盛行导致高校学生党建的核心价 值观弱化。1980 年以来社会中凸显了一种新的社会价 值观一一中国社会的个体化[4]。这种个体化呈现出了 众多的 “无公德的个人” 现象, 是一种极端形式的自 我中心观念。其次, 目前高校学生党建工作制度不够 完善, 缺少必要的长效机制。高校学生党支部普遍存 在教育缺失现象, 很多党支部把党员发展放在党支部 工作的首位, 导致学生党员的理论知识相对贫乏, 缺 少党性修养, 影响党员质量。

\section{2. 高校学生党建社会工作的含义}

结合国内和国际权威表述, 高校学生党建社会工 作, 是指在党的领导下, 运用社会工作专业理念与方 法, 为高校大学生基层党组织、大学生党员及大学生 提供以恢复或强化能力, 融入集体、发挥功能等为目 的的专业服务, 从而对学生党员和学生党组织进行先 进性的建设, 增强学生党员自我教育、自我管理、自 我服务的意识和能力。

大学生党建社会工作的定位为服务大学生、服务 党组织及大学生党员。以服务高校学生为主线, 以服 务学生党组织及学生党员为方向, 以党建社工服务技
能为手段, 通过大学生党建社会工作者发动大学生党 员服务大学生, 党员带动大学生服务社会, 探讨党群 共建、党群共融的发展新模式。

\subsection{1. 以服务高校学生为主线}

高校学生是正在接受基础高等教育和专业高等 教育的一群人, 服务高校学生作为高校学生党建社会 工作的主线, 主要做实两个基础: 一是价值观激励, 鼓励支持大学生在班级、学生组织中任职, 积极培养 思想上积极上进的大学生提交入党申请书、发展入党 积极分子、预备党员等, 坚定高校大学生红心向党的 信念。二是微环境优化, 积极为大学生提供心理咨询、 学习辅导等措施, 帮助其更好地融入大学生活、提升 自身能力、奠定坚实基础。鼓励和推荐优秀大学生参 与文化专业技能比赛, 参与活动组织与建设, 发挥自 身才能, 使大学生成为社会各个领域中的标兵。

\subsection{2. 以服务学生党组织及学生党员为重点}

高校学生党员社会工作服务重点要做好学生党 组织及学生党员服务, 一方面增强学生党员的政治归 属感, 为学生党员提供微环境优化服务, 通过心理咨 询、学习辅导、社团组织等措施, 进一步推动学生党 员参与集体生活, 融入群众, 发挥学生党员的带头作 用。另一方面加强对相关党务工作进行培训, 主要内 容包括协助党组织做好党务会务工作、文档工作等行 政事务性工作; 协助党组织做好日常大学生党员管理 工作; 协助党代表开展联系普通大学生工作; 通过开 发和运营新媒体、自媒体, 扩大大学生党组织的影响 力。

\subsection{3. 以服务社会为根本}

高校学生党建社会工作者在高校学生党员、学生 党组织与社会之间构建联系, 使高校学生党员在党组 织、校园、社会中践行党员的社会责任。通过组建大 学生党员志愿者服务队、建立大学生党员志愿者服务 站等多种形式开展志愿服务活动, 不断创新服务载体, 积极利用高校、社会组织等周边服务资源, 建立志愿 服务合作关系。依托高校党员活动室, 打破地域、单 位、系统的限制, 引进各类群众团体、院校组织、志 愿服务队等社会力量, 开展经常性大学生党员社会工 作服务。为高校学生提供就业指导等服务, 对于就业、 创业的高校学生提供有利的支持, 为其回报社会奠定 现实基础。 


\section{3. 高校学生党建社会工作的框架体系构建}

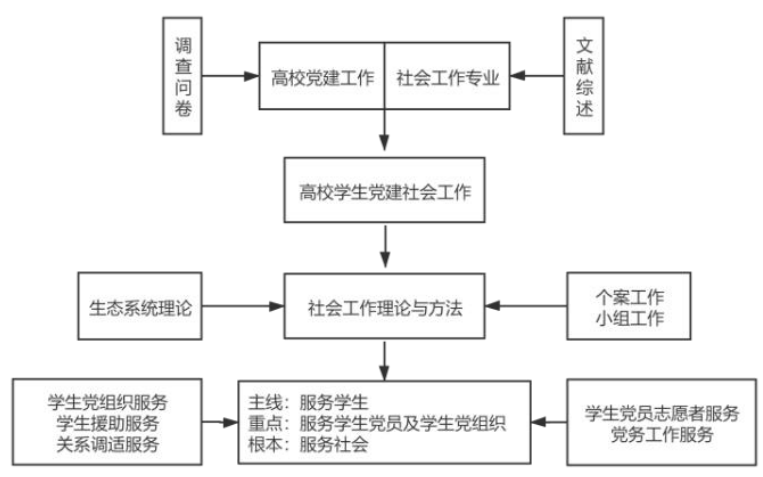

图 1高校学生党建社会工作框架体系

\section{1. 以生态系统理论为指导}

生态系统理论指导高校学生党建社会工作的应用, 高校学生、学生党员与他人、与学生组织、与学生党组 织处于相互作用之中, 高校学生党建社会工作者的目标 不应只关注其个人的行为, 还应该关注高校各个子系统 之间和高校学生的相互影响。将高校学生党建与社会工 作专业融合, 依托高校基层党组织、学生会、学生社团、 班级、宿舍等高校社会组织系统、教师、同学等社会支 持系统发展高校学生党建社会工作, 为高校大学生、学 生党员、大学生基层党组织提供社会工作专业服务。

\section{2. 以小组工作方法为依托}

高校学生党建社会工作者依托小组工作方法, 在 不打破原有党组织架构的前提下, 党员根据自身特点 和需求, 自主选择个性化党小组。个性化党小组面向 全体同学开放, 非党员学生可向党小组提出申请, 参 加小组活动。一方面围绕党员支援服务设置党小组。 根据党员学生兴趣爱好、技能专长、就读专业年纪等, 把同专业、同年级、同爱好的党员编入同一党小组, 使党组织开展活动更有针对性和吸引力。另一方面围 绕党员作用设置党小组。结合开展党员学生承诺制、 党员学生责任制、评星定级等活动, 根据不同制度具 体情况设立党小组。

\section{3. 高校学生党建社会工作的服务内容构建}

\section{3. 1. 创新高校学生党组织培养方式}

高校学生党建社会学生党组织服务是指高校学 生党建社会工作者面向高校学生基层党组织, 提供价 值观激励服务, 不断增强学生党员对于党组织的归属 感。

高校学生党建社会工作一方面要协助学生党组 织做好党员培养发展工作, 创新党员培养方式。通过 联合培养、多方培养、“火线”培养等培养方式，推动
高校学生党员整体素质的提升, 创新高校学生党员考 察方式，坚持“即席演讲”与“现场答辩”相结合的方式， 多层次多方面了解考察对象情况。另一方面要开展思 想政治教育工作。以学生基层党组织为核心，整合班 级、学生组织、学生社团等学生组织资源, 开展 “建 党 100 周年” 系列活动, 不断增强学生党员对党组织 的归属感。开展学生党员志愿服务活动, 密切联系同 学, 促进学生党员发挥先锋模范带头作用。

\section{3. 2. 促进高校资源协调整合，推动社会工 作服务}

高校学生党建社会工作学生援助服务是指协调 相关人员为有需要的高校学生提供法律、医疗、就业 等方面的咨询服务、链接资源服务、心理疏导服务等。 高校学生党建社会工作者通过调查问卷调研需求, 帮 助困难党员、困难学生申请国家励志奖学金、低保金、 大病医疗救助金等, 使生活在困难底线上的学生得到 最及时、最有力的帮助。通过对困难学生开展学习能 力、学习方法、技术帮扶能方面的辅导, 依托学生基 层党组织, 运用多种技术手段, 采取办培训班、开现 场会、远程网络教育等方式进行思想教育。高校学生 党建社会工作者通过高校需求评估, 推进 “扶助式” 平台、“联络式” 平台、“服务式” 平台、“文化式”平 台等多个平台建设，统筹高校资源。针对思想上有问 题的学生党员, 高校学生党建社会工作者采取认知行 为疗法、任务中心模式等社会工作专业方法, 改变学 生党员对党的政策、组织建设等方面的错误认知与行 为, 从而进一步改变目前部分学生党员补交党费、不 参与组织生活、不做组织交办的工作任务的现状, 提 升学生党员党性修养。

\section{3. 3. 扩大高校学生党员志愿者服务范围}

学生党员志愿者是指学生本人自愿向学生基层 党组织进行申请, 通过自己的带头和桥梁作用, 无偿 为学生和他人提供服务和帮助, 影响和带动周围同学、 学生党员。扩大高校学生党员志愿服务范围, 不仅包 括服务人员的范围，服务高校学生、基层党组织、社 会，还包括服务内容的范围。服务内容主要包括：政 府会议期间进行政策法规宣传, 及时学习宣传党的路 线、方针、政策。协助学校党委、团委宣传资助、就 业、学校相关的法律法规与政策。学生意见收集, 深 入了解高校学生心声, 收集反馈学生的意见和建议, 及时向上级基层党组织报告高校学生的突发事件和 其他事件。文明新风维护，在高校内开展各类文明创 评活动, 弘扬先进, 倡导文明新风, 营造团结互助的 氛围, 抵制法轮功等各种邪教组织。就业创业服务, 以即将毕业的大学生为主要的服务对象, 开展免费就 业创业技能培训，推荐再就业，指导创业，协调落实 就业和创业优惠政策等服务。文体活动服务, 通过学 生组织、学生社团等各类文体活动队, 组织高校学生 开展丰富多彩、健康有益的文体娱乐活动。其他特色 
服务, 结合高校学生实际需求, 发挥学生党员志愿者 特长, 开展其他各类特色服务活动。

\section{4. 结论}

高校学生党建社会工作概念的提出对高校学生 党建工作提出了一种全新的工作思路。高校学生党建 社会工作运用社会工作专业理论与方法为高校学生 提供价值观激励, 微环境优化等服务。虽说近年来对 于党建社会工作的研究逐渐增多, 但对于高校学生党 建社会工作领域的研究相对较少, 本论文对于该领域 的研究具有指导实践的理论意义。但本文仅仅通过生 态系统理论的视角看待高校学生党建工作, 认为高校 学生、学生党员所存在的问题与需求与其所处的生态 环境密切相关, 没有将学生自身的主观因素进行深度 考虑, 相对比较片面。未来可以将其他社会工作专业 理论与方法引入高校学生党建社会工作中, 例如理性 情绪治疗模式、认知行为治疗模式等, 通过个案工作、 小组工作调整服务对象的认知、情感、意志、行为, 从而推动高校学生党建工作的进一步完善与发展。

\section{REFERENCES}

[1] Cheng Bing;Liu Jia. Social Work Method and Construction of “Three Type" Student Party Branch in Colleges .Future and Development,2016,40(06):109-112+108.

[2] Wei Shuang.The application of the "group work" method in the party building work of students in universities[J].China Youth Study,2006(05):85$87+81$.

[3] WanYan.The Responses from Social Work to the Structural Dilemmas of Party Building for College Students in the New Era:A Perspective of Interoperable Governance[J].Journal of East China University of Science and Technology(Social Science Edition,2019,34(02):110-116.

[4] Yan Yunxiang.The Individualization of Chinese Society[M],Shanghai Translation Publishing House, 2012,326-345.

[5] Zhang Huijie.Party Social Work Practice[M],

Central South University Press,2018. 